\title{
ERRATUM
}

\section{Erratum to: Recovery of gonadal development in tiger puffer Takifugu rubripes after exposure to $17 \beta$-estradiol during early life stages*}

HU Peng (胡鹏) $)^{1,2}$, LIU Bin (刘滨 $)^{2}$, MENG Zhen (孟振 $)^{2}$, LIU Xinfu (刘新富 $)^{2, * *}$, JIA Yudong (贾玉东) $)^{2}$, YANG Zhi (杨志 $)^{3}$, LEI Jilin (雷雯霖) $)^{2}$

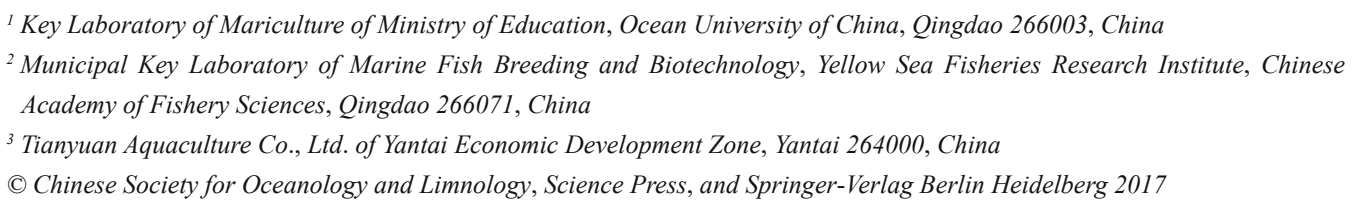

\section{Erratum to: Chinese Journal of Oceanology and Limnology}

Vol. 35 No. 3, P. 613-623, 2017

http://dx.doi.org/10.1007/s00343-017-6016-6

A mistake was found in Section 2.2. The current expression is "In each treatment group, juveniles were exposed to E2 at the set concentration for $2 \mathrm{~h}$ once a day from 15 to $100 \mathrm{dph}$." The correct version should be "In each treatment group, juveniles were exposed to E2 at the set concentration for $2 \mathrm{~h}$ once two days from 15 to 100 dph."

The online version of the original article can be found at: http://dx.doi.org/10.1007/s00343-017-6016-6.

* Supported by the China Agriculture Research System (No. CARS-50-G20), the National Natural Science Foundation of China (No. 31402284), and the National High Technology Research and Development Program of China (863 Program) (No. 2012AA10A413-2)

** Corresponding author: liuxf@ysfri.ac.cn 